\title{
Itinerários em análise social
}

Charles Tilly

Tradução de Alexandre M orales

Retrospecto em demasia pode lhe fazer mal. Se em meio a um tráfego pesado e rápido você dirigir com os olhos o tempo todo no retrovisor, isso Ihe dará uma perfeita visão dos caminhões que estão no seu encalço, mas facilmente poderá causar uma desastrosa colisão com os veícul os à sua frente. M esmo assim, isso Ihe ajudará eventualmente a rever a estrada na qual está viajando. E a planejar o resto de sua jornada. Poderá ainda contribuir para que outros planejem jornadas diferentes, talvez melhores.

A jornada em questão atravessa o terreno da análise social: a interpretação sistemática e cética das interações humanas em qualquer escala, desdeos encontros furtivos dos amantes até a ascensão e queda dosimpérios. Permitam-meidentificar um conjunto deescolhas - ou encruzilhadas, como também poderiam ser chamadas - a serem confrontadas por qualquer um que siga a carreira da análise social. M ais à frente identificarei e explicarei as escolhas quefiz, mas apenas para clarificar quais outras escolhas osjovensque cogitam seguir carreira no campo da análise social poderão fazer, e por quê.

Considerem quatro encruzilhadas, cada qual requerendo uma escolha entre aproximar-se ou afastar-se em relação a certo destino. Chame-as Presente versus Passado, Ação versus C ontexto, Poder versus Vulnerabilidade e Prescrição versus Explicação. À diferença dos cruzamentos rodoviários, em ângulo reto, essas encruzilhadas permitem aos viajantes escolher entre múltiplos ângulos de aproximação ou afastamento, bem como fazer o retorno 
e seguir mais de um itinerário. Entretanto, simplificará minha discussão simular que estamos lidando com escolhas de tipo sim-ou-não.

Presente versus Passado? No momento em que qualquer analista social tenha sido efetivamente capaz de estruturar uma interpretação sistemática e cética de uma interação humana, essa interação já se terá incorporado ao passado. Somente os locutores esportivos e os repórteres tel evisivos chegam perto de fazer observação e análise simultaneamente. Apesar disso, alguns analistas se concentram nas questões humanas atuais, outros buscam identificar conexões entre passado e presente, e outros ainda fixam seu olhar em eventos e pessoas de tempos remotos. 0 sargumentos em favor do presente sugerem que as pessoas se preocupam sobretudo com o que está acontecendo agora, que as interações em curso estão moldando o futuro humano e que os investigadores do presente podem se fiar em suas próprias observações e intervenções, em vez de padecer das distorções da documentação e das fal has da memória. 0 sargumentos em favor do passado afirmam que 0 presente opera dentro de limites legados pelo passado, queal guns processos levam um longo tempo para se definir, demandando portanto análises de longo prazo, e que a interação humana passada oferece um vasto laboratório para a identificação de regularidades persistentes nos processos sociais.

E quanto a Ação versus C ontexto? 0 s analistas sociais podem focalizar os humanos desempenhan do efetivamente ações importantes ou recuar para situar esses mesmos humanos em seus tempos, lugares e contextos sociais. O s economistas, por exemplo, comumente presumem que podem produzir explicações adequadas do comportamento humano identificando as oportunidades, as preferências e os recursos que caracterizam os indivíduosimediatamente antes de comprarem, venderem, produzirem ou consumirem. O s antropólogos, em contraste, costumam argumentar que o comportamento humano depende fortemente da localização dos indivíduos e grupos em redes específicas de relações sociais, cultura e meio ambiente. Ação equivale a aproximar-se da vida social tal como os indivíduos a vivenciam, um a um; contexto, a aproximar-se do nosso reconhecimento ocasional de que as conexões importam.

Pense em Poder versus Vulnerabilidade, uma escolha bem mais complicada. D e um lado, os analistas sociais podem focalizar sua atenção naquelas pessoas, posições, grupos e instituições de maior impacto nas vidas de outras pessoas: profetas, patriarcas, presidentes, generais, financistas e até mesmo autores influentes. D e outro, os analistas sociais podem seguir meu amigo James Scott e argumentar: uma vez que a maioria das pessoas, na 
maior parte do tempo, está sofrendo as conseqüências do poder sem poder exercer muita influência sobre ele, os mais vulneráveis merecem todo 0 apoio que possam ter e, em conseqüência, os analistas deveriam concentrar sua atenção em como aquelas pessoas relativamente sem poder lidam com a opressão e com as dificuldades. A escolha se torna complicada porque não envolve simplesmente alinhar-se com o poderoso ou com o fraco. $0 \mathrm{~s}$ analistas do poder freqüentemente invejam, odeiam ou culpam seu objeto, enquanto os analistas da vulnerabilidade freqüentemente deploram a incapacidade das pessoas comuns de se comportarem como eles prefeririam.

Isso nos leva a Prescrição versus Explicação. Alguns analistas sociais se concentram em projetar, advogar ou contribuir para organizar o que consideram modos de vida superiores. 0 utros se concentram em explicar por que a vida social toma a forma que tem. Essa simples oposição, entretanto, obscurece a interdependência entre prescrição e explicação. N um sentido, as preferências acerca de estados de coisas desejáveis e indesejáveis inevitavelmente influenciam o modo como os analistas sociais el egem, concebem e justificam suas investigações. N outro sentido, todo programa político e moral invariavelmente associa sua identificação de resultados desejáveis a três outras ordens de afirmações: afirmações sobre fatos, relativas ao que existe atualmente no mundo; afirmações sobre possibilidades, relativas a formas alternativas de existência e afirmações de causa e efeito, explicando como o mundo social poderia passar da sua indesejável condição presente para outra mais desejável. Afirmações sobre fatos, possibilidades e relações de causa e efeito empurram todo programa prescritivo para o terre no da explicação.

A té aqui, o meu próprio itinerário tendeu a favorecer o passado em vez do presente, o contexto em vez da ação ea explicação em vez da prescrição, ao passo que procurou um meio-termo entre vulnerabilidade e poder. Ao longo do tempo, devotei quase que igual energia a analisar as estruturas de poder em mudança, as formas de conflito popular em mudança e as interações entre elas. Tais escol has oferecem a vantagem de um aprendizado cumulativo e uma perspectiva comparada acerca das emergências dos dias dehoje. Impõem, porém, o custo da marginalidade diantedos debates contemporâneos mais candentes. Tenho constantemente pensado que o meu trabalho descascava problemas que atraíam ampla atenção mas, enquanto esquadrinhava as implicações de minhas análises, o debate público já se havia deslocado para outras questões. Você só deve seguir meu itinerário se almejar fazer a sua contribuição não neste instante, mas no longo prazo. 
Felizmente, as outras escol has permanecem abertas e convidativas. No curso desse mesmo longo prazo, aqueles que escolherem o presente em vez do passado, a ação em vez do contexto, a prescrição em vez da explicação e a vulnerabilidade ou o poder, em vez do meio-termo, também estarão viajando através do acidentado, mas recompensador, terreno da compreensão humana.

Universidade de Columbia, 15 de setembro de 2002.

\section{Resumo}

Itinerários em análise social

0 texto discorre sobreo conjunto de escolhas - ou encruzilhadas, como prefere o autor -, com as quais se confrontam os analistas dos fenômenos da vida social. As escolhas entre "presenteversuspassado", "ação versus contexto", "poder versus vul nerabilidade" e "prescrição versus explicação" permitem ao estudioso el eger entremúltiplos ângulos de aproximação (ou afastamento) no que concerne à forma de construir a análise social. 0 autor afirma que o seu próprio itinerário favoreceu o passado em vez do presente, 0 contexto em vez da ação e a explicação em vez da prescrição, ao mesmo tempo em que procurou se posicionar no meio termo entre vulnerabilidade e poder.

Palavras-chave: Trajetória intelectual; Análise social; Charles Tilly.

Texto recebido em $10 /$ 2004 e aprovado em $10 / 2004$.

CharlesTilly éprofessor deciênciassociaisnacá tedra Joseph L. Buttenwieser da Universidade de Columbia. E-mail: ct135@columbia.edu.

\section{Abstract}

Itineraries in social analysis

The author identifies a set of choices - crossroads, as he prefers to call them - confronted by anyone who makes a career of social analysis. "present versus past", "action versus context", "power versusweakness", and "prescription versusexplanation" arecrossroads that allow travelers to choose among multiple angles of approach (or avoidance) in the terrain of social analysis. Later he identifies and explains the choices he made: his own itinerary up to this point has generally favored the past over the present, context over action, and explanation over prescription, while seeking a middle ground between weakness and power.

Keywords: Intellectual trajectory; Social analysis; Charles Tilly. 